\title{
Konservasi Genetik Ikan Kakap Putih (Lates calcarifer, Bloch, 1790) melalui Pendekatan DNA Barcoding dan Analisis Filogenetik di Sungai Kumbe Merauke Papua
}

\author{
Dandi Saleky', Muhammad Dailami²* \\ 1 Jurusan Manajemen Sumberdaya Perairan, Universitas Musamus \\ Jl. Kamizaun Mopah Lama, Merauke, 99600 Indonesia \\ 2Program Studi Budidaya Perairan, Fakultas Perikanan dan Ilmu Kelautan, Universitas Brawijaya \\ J. Veteran, Kota Malang, 65149 Indonesia \\ Email : muhdailami@ub.ac.id
}

\begin{abstract}
Genetic Conservation of White Snapper Fish (Lates calcarifer, Bloch, 1790) through DNA Barcoding Approach and Phylogenetic Analysis in Kumbe River Merauke Papua
\end{abstract}

Genetic data is very important as the basis for fisheries management and conservation related to connectivity between regions and population structure. White snapper Fish is one of the fish that has high economic value which is utilized either by its meat or by its swim bladder. This research was aimed to identify the species of white snapper fish were collected from the Kumbe River, Merauke Regency, Papua using the Cytochrome Oxidase I gene. The results shows that this sample is a species of Lates calcarifer, Bloch, 1790 with 100\% similarity. The haplotype of white snapper fish from Merauke has similarities with the haplotype from Australia, Malaysia and China, this indicating that there is gene flow and connectivity among those locations. The phylogenetic tree explains the grouping of species based on genetic distance and the level of DNA Sequences similarities. Molecular approach can be used in the management and conservation of fish with high economic value.

Keywords: Lates calcarifer, Kumbe River, COl gene, Haplotype, Phylogenetic tree

\begin{abstract}
Abstrak
Data genetik sangat penting sabagai dasar pengelolaan dan konservasi perikanan yang berhubungan dengan konektivitas antar wilayah dan juga truktur populasi. Ikan kakap putih termasuk dalam ikan yang memiliki nilai ekonomis tinggi yang dimanfaatkan baik daging ataupun gelembung renangnya. Penelitian ini dilakukan dengan tujuan mengidentifikasi spesies ikan kakap putih putih yang dikoleksi dari Sungai Kumbe, Kabupaten Merauke Papua dengan menggunakan gen Sitokrom Oksidase I. Hasilnya menunjukkan bahwa bahwa sampel ini adalah spesies Lates calcarifer, Bloch, 1790 dengan kemiripan 100 \%. Haplotype ikan kakap putih asal Merauke memiliki kesamaaan dengan haplotype yang berasal dari Australia, Malaysia dan Cina hal tersebut mengindikasikan adanya sharring genetik dan konektivitas antar lokasi. Pohon filogenetik yang terbentuk memperlihatkan pengelompokan spesies yang didasarkan pada jarak genetik dan tingkat similaritas sekuen DNA. Berdasarkan data ini, Pendekatan molekuler dapat digunakan dalam kegiatatan pengelolaan dan konservasi spesies ikan ekonomis penting.
\end{abstract}

Kata Kunci: Lates calcarifer, Sungai Kumbe Merauke, Gen COI, Haplotype, Pohon filogenetik 


\section{PENDAHULUAN}

Ikan kakap putih (Lates calcarifer, Bloch, 1790) adalah ikan yang memiliki nilai ekonomis tinggi baik untuk dikonsumsi dalam negeri ataupun sebagai komoditas eksport (Ibrahim et al., 2014). Permintaan pasar akan ikan kakap putih baik daging dan gelembung renangnya cukup tinggi, menjadikan ikan kakap putih sebagai spesies target oleh nelayan et al., 2016). Laju pemanfaatan sumberdaya perikanan yang tinggi, kerusakan habitat, dan perubahan iklim cenderung dapat berpengaruh terhadap keragaman genetik spesies ikan termasuk ikan kakap putih (Martinez et al., 2018). Ekplorasi dan eksploitasi sumberdaya ikan sebaiknya dilakukan dengan pendekatan konservatif yang mana kegiatan tersebut dapat mencegah terjadinya penurunan populasi ikan (Akbar et al., 2014).

DNA barcoding memiliki keunggulan dalam identifikasi spesies dengan tingkat akurasi yang tinggi dibandingkan dengan pengamatan morfologi (Madduppa et al., 2017; Saleky et al., 2020). DNA barcoding berdasarkan marka gen Sitokrom Oksidase Subunit I (COI) secara luas dipergunakan dalam identifikasi spesies dan studi keanekaragaman hayati (Leatemia et al., 2018; Thu et al., 2019). Gen COl digunakan sebagai marker DNA yang efektif pada spesies ikan dari perairan berbeda di seluruh dunia (Wang et al., 2012) dan telah diaplikasikan pada berbagai jenis ikan di berbagai wilayah seperti di Australia (Ward et al.,2008), India (John et al., 2010), dan AsiaPasifik (Yue et al., 2009).dan berbagai wilayah di dunia termasuk di Indonesia (Dailami et al., 2021a).

Keanekaragaman hayati saat ini dianggap sebagai bagian dari hasil evolusi dari perubahan iklim dan tektonik di masa lalu (Weigand et al., 2013). Pengelolaan sumberdaya ikan kakap putih yang berkelanjutan diperlukan proses pemantauan dan klarifikasi yang berhubungan struktur populasi di alam melalui analisis filogenetik (John et al., 2010) maupun keragaman genetik populasi (Nugraha et al., 2011). Hubungan genetik antar spesies dalam satu populasi dan antar populasi dapat diketahui melalui rekonstruksi filogenetik (Pramono et al, 2017; Saleky et al., 2020).

Perairan Merauke kaya akan sumberdaya ikan kakap putih, pemanfaatannya tidak terbatas pada daging tetapi juga gelembung ikan yang memiliki nilai ekonomis yang jauh lebih tinggi. Eksploitasi berlebih akan mengakibatkan penurunan keanekaragaman spesies yang diawali dengan penurunan keanekaragaman genetik (Yusron, 2005). Kegiatan konservasi diawali dengan dilengkapinya berbagai informasi seperti bioekologi, taksonomi termasuk di dalamnya informasi genetik (Nuryanto \& Solihin, 2006). Informasi tersebut sangat diperlukan dalam rangka menentukan metode konservasi yang tepat. Penelitian ini bertujuan untuk menganalisis keragaman genetik ikan kakap putih (Lates calcarifer, Bloch, 1790) sebagai dasar dalam pengelolaan dan konservasi sumberdaya hayati ikan kakap putih di perairan Merauke Papua.

\section{MATERI DAN METODE}

Sampel ikan kakap putih dikoleksi dari Sungai Kumbe Kabupaten Merauke, Papua (Gambar 1), Sampel ikan kakap putih dikoleksi menggunakan gillnet dan diidentifikasi menggunakan fishbase (www.fishbase.org). Sampel jaringan sirip yang diperoleh kemudian disimpan dalam botol sampel berisi ethanol $96 \%$. Analisis molekuler untuk mendapatkan fragmen DNA dilakukan di Laboratorium Biodiversitas Indonesia Bali.

Sekuen DNA ikan kakap putih diperoleh melalui analisis molekuler. Primer yang digunakan dalam penelitian ini menggunakan 2 primer yang secara umum dipergunakan dalam identifikasi ikan yaitu primer forward FISH-BCL: 5'TCAACCAACCACAAAGACA-3', dan primer reverse FISH-BCH: 5' TAGACTTCTGGGTGGCCAA-3'. Reaksi PCR menggunakan volume $25 \mu$ dengan jumlah template DNA 1 - $4 \mu$ l. Profil PCR meliputi denaturasi awal $94^{\circ} \mathrm{C}$ selama 15 detik, denaturasi $94{ }^{\circ} \mathrm{C}$ selama 30 detik, annealing pada $50^{\circ} \mathrm{C}$ selama 30 detik dan extention pada $72^{\circ} \mathrm{C}$ selama 45 detik dan final extention pada $72^{\circ} \mathrm{C}$ selama 10 menit, semua proses tersebut dilakukan dengan pengulangan sebanyak 40 siklus. Hasil PCR 
positif kemudian dikirim untuk di sekuensing pada lembaga penyedia jasa sekuensing

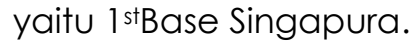

Hasil sekuensing yang diperoleh dari perusahaan jasa sekuensing kemudian diedit menggunakan model ClustalW (1.6) dengan menggunakan program MEGA $X$ (Moleculer Evolutionary Genetic Analysis). Data yang telah diedit kemudian dicocokan dengan data genetik pada GeneBank di NCBI (National Center for Biotechnology Information) dengan menggunakan BLAST (Basic Local Alignment Search Tool). Data genetik didownload dari GenBank (https://www.ncbi.nlm.nih.gov/) dan dijadikan sebagai pembanding ikan gulamah asal Merauke dan ikan kakap putih dari daerah lain. Perhitungan jarak genetik (D) antar spesies dihitung dan juga merekonstruksi pohon filogenetik dengan menggunakan aplikasi Mega X (Kumar et al., 2018). Rekonstruksi pohon filogenetik ikan kakap putih menggunakan metode NeighbourJoining (NJ) dengan model Kimura 2parameter, nilai bootstrap 1000x. Analisis haplotype menggunakan software DnaSP (Rozas et al., 2017).

\section{HASIL DAN PEMBAHASAN}

Panjang sekuen DNA adalah 660 pb diperoleh dari analisis molekuler. Hasil identifikasi menggunakan BLAST di GenBank, 2 spesies yang dikoleksi dari Sungai Kumbe Kabupaten Merauke Papua ada benar ikan kakap putih (Lates calcarifer, Bloch, 1790) dengan tingkat similaritas $100 \%$. Hasil identifikasi menggunakan teknik DNA barcoding memiliki potensi yang luas dalam perkembangannya, seperti studi identifikasi dalam berbagai tahapan kehidupan, status konservasi, taksonomi (Dailami et al., 2021b), biogeografi dan inventarisasi keanekaragaman hayati (Achmad, Subur, \& Akbar, 2020; Ran, Li, Qi, Li, \& Kong, 2020). Komposisi nukleotida dan komposisi rata-rata basa DNA yang ditemukan pada kedua sampel ikan kakap putih adalah Thymine (T) (29.4\%), Cytosine (C) (30\%), Adenine (A) (21.4\%), dan Guanine (G) (19.4\%). Kedua sampel ikan kakap putih yang dikoleksi juga tidak terjadi mutasi genetik yang mana kedua sampel tersebut memiliki sekuen yang identik.

Sebanyak tujuh haplotipe ikan kakap putih diperoleh dalam penelitian ini dan

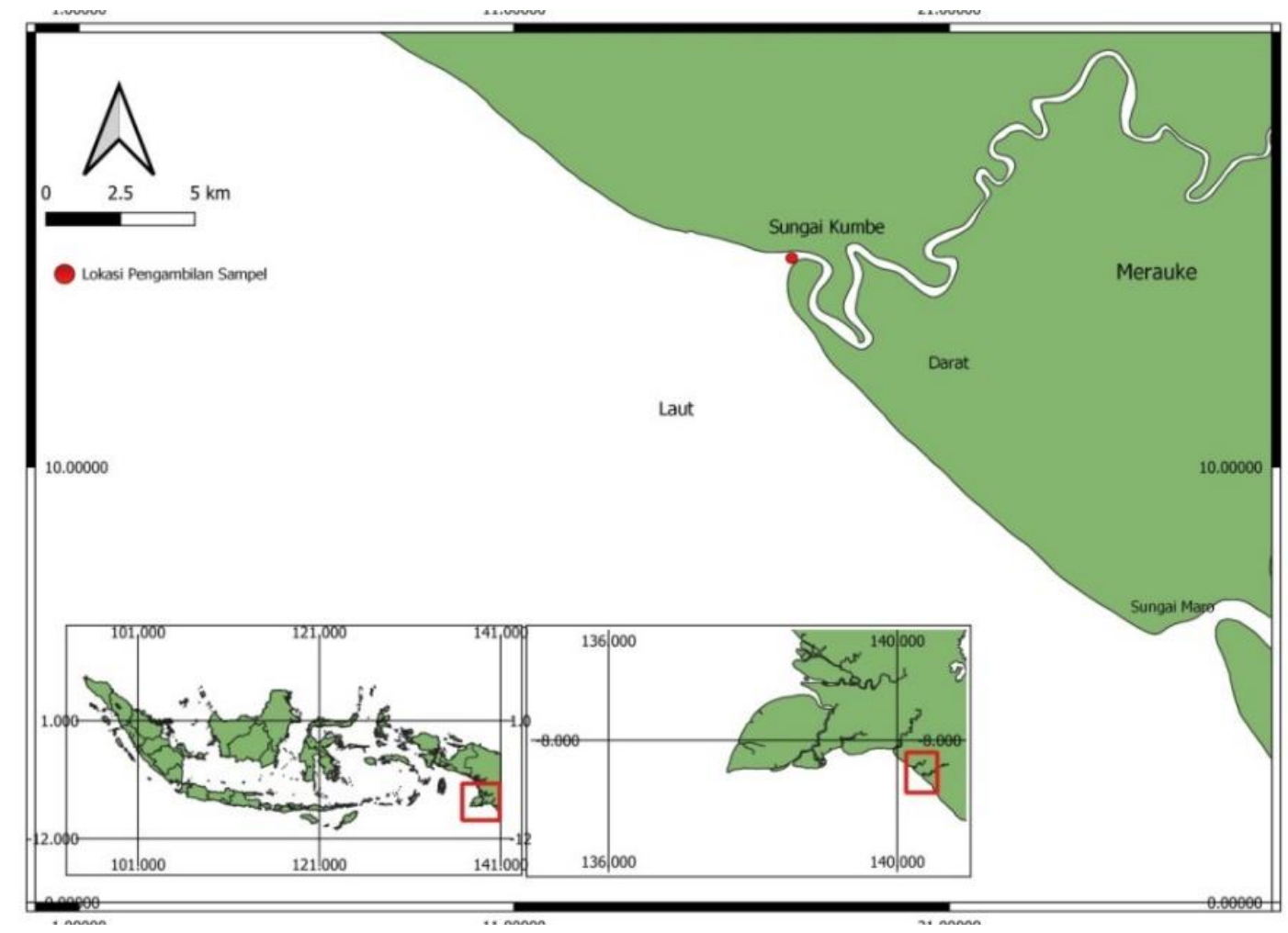

Gambar 1. Peta pengambilan sampel ikan kakap putih (Lates calcarifer, Bloch, 1790) 
tersebar diberbagai wilayah perairan. Jenis haplotype akan bertambah dengan semakin banyaknya jumlah sampel yang dianalisis. Variasi haplotype sangat menentukan tingkat keragaman genetik yang menjadi faktor kunci dalam kelangsungan hidup suatu spesies (Rachmat et al., 2016). Perubahan dalam variasi haplotype sangat dipengaruhi oleh berbagai faktor seperti seleksi alam, pergeseran genetik, mutasi, dan aliran gen yang mengarah pada terbentuknya spesies baru (Adams et al., 2019).

Hasil analisis memperlihatkan ikan putih asal sungai Kumbe Merauke memiliki kesamaan haplotype dengan sampel ikan kakap putih yang berasal dari Australia, China dan Malaysia. Hasil ini memperlihatkan terjadinya sharring genetik antar lokasi-lokasi tersebut sehingga memiliki haplotype yang sama (Díaz-Ferguson et al., 2010).

Jarak genetik digunakan sebagai dasar dalam mempelajari evolusi molekuler, rekonstruksi filogenetik dan perkiraan waktu evolusi (Sohpal, 2013). Analisis jarak genetik dilakukan dengan menggunakan model Kimura 2-Parameter (Tabel 1). Hasil analisis jarak genetik diketahui 2 individu ikan kakap putih yang dikoleksi dari Sungai Kumbe Merauke memiliki haplotype yang sama dengan jarak genetik 0.000 . Jarak genetik 0.000 juga diperoleh antar sampel dari merauke dengan sampel yang $L$. calarifer (KX781875- Australia), L. calarifer (EU189378Australia Selatan) dan L. calarifer (GU459274China). Jarak genetik terjauh ikan kakap putih asal Merauke adalah dengan sampel ikan

Tabel 1. Sekuen DNA Lates calcarifer, Lates niloticus dan Lates japonicas yang digunakan dalam rekonstruksi filogenetik termasuk lokasi, nomor akses dari National Center for Biotechnology Information (NCBI).

\begin{tabular}{lllll}
\hline No & Spesies & Lokasi & Acc. No & Sumber \\
\hline 1 & L. calcarifer & Gujarat India & JX983354 & $\begin{array}{l}\text { (Khedkar, Jamdade, Naik, } \\
\text { David, \& Haymer, 2014) }\end{array}$ \\
2 & L. calcarifer & Indonesia & GU674017 & - \\
3 & L. calcarifer & Bangladesh & MK572284 & (Rahman et al., 2019) \\
4 & L. calcarifer & Malaysia & KY849521 & (Azmir et al., 2017) \\
5 & L. calcarifer & Indonesia & KU692587 & (Dahruddin et al., 2017) \\
6 & L. calcarifer & Polinesia & JQ431879 & (Hubert et al., 2012) \\
7 & L. calcarifer & Australia & KX781875 & (Mitchell et al., 2019) \\
8 & L. calcarifer & Australia & KX781858 & (Mitchell et al., 2019) \\
9 & L. calcarifer & Myanmar & MH235652 & (Segura-García, et al., \\
& & & 2018) \\
10 & L. calcarifer & India & JF919828 & (John et al., 2010) \\
11 & L. calcarifer & India & JF919827 & (John et al., 2010) \\
12 & L. calcarifer & India & KC508501 & (Rajasekar et al., 2012) \\
13 & L. calcarifer & India & KC508500 & (Rajasekar et al., 2012) \\
14 & L. calcarifer & Australia Selatan & EU189379 & (Ward et al., 2008) \\
15 & L. calcarifer & Australia Selatan & EU189378 & (Ward et al., 2008) \\
16 & L. calcarifer & Vietnam & MK777481 & (Thu et al., 2019) \\
17 & L. calcarifer & Bangladesh & MH087052 & (Ahmed et al., 2020) \\
18 & L. calcarifer & Bangladesh & MG969518 & (Ahmed et al., 2020) \\
19 & L. calcarifer & China & GU459305 & (Zhang, 2010) \\
20 & L. calcarifer & China & GU459274 & (Zhang, 2010) \\
21 & L. japonicus & Jepang & LC269832 & (Iwatsuki et al., 2018) \\
22 & L. niloticus & Mesir & LC487183 & (Ali et al., 2020) \\
\hline & & & &
\end{tabular}


kakap putih yang berasal dari India, Vietnam maupun Bangladesh. Beberapa faktor dapat menjadi penyebab terjadinya perbedaan genetik misalnya kondisi habitat yang berbeda, tidak adanya konektivitas antar lokasi maupun jarak geografis.

Jarak genetik yang sangat kecil antara ikan kakap putih asal Merauke dengan ikan kakap putih yang berasal dari Australia dan China menunjukkan bahwa ada konektivitas antar wilayah melalui arus laut. Beberapa kemungkinan yang menyebabkan spesies - spesies dari lokasi yang berbeda memiliki kemiripan secara genetik misalnya adanya sharring genetik (Leatemia et al., 2018), konektivitas antar wilayah (Díaz-Ferguson et al., 2010), kesamaan habitat dan pada organisme laut cenderung melalui proses migrasi dan arus laut sebagai media transfer (Saleky et al., 2016).

Filogenetik molekuler adalah aspek fundamental dari analisis evolusi yang bergantung pada jarak \& karakter metode berbasis matematis (Sohpal, 2013). Rekonstruksi

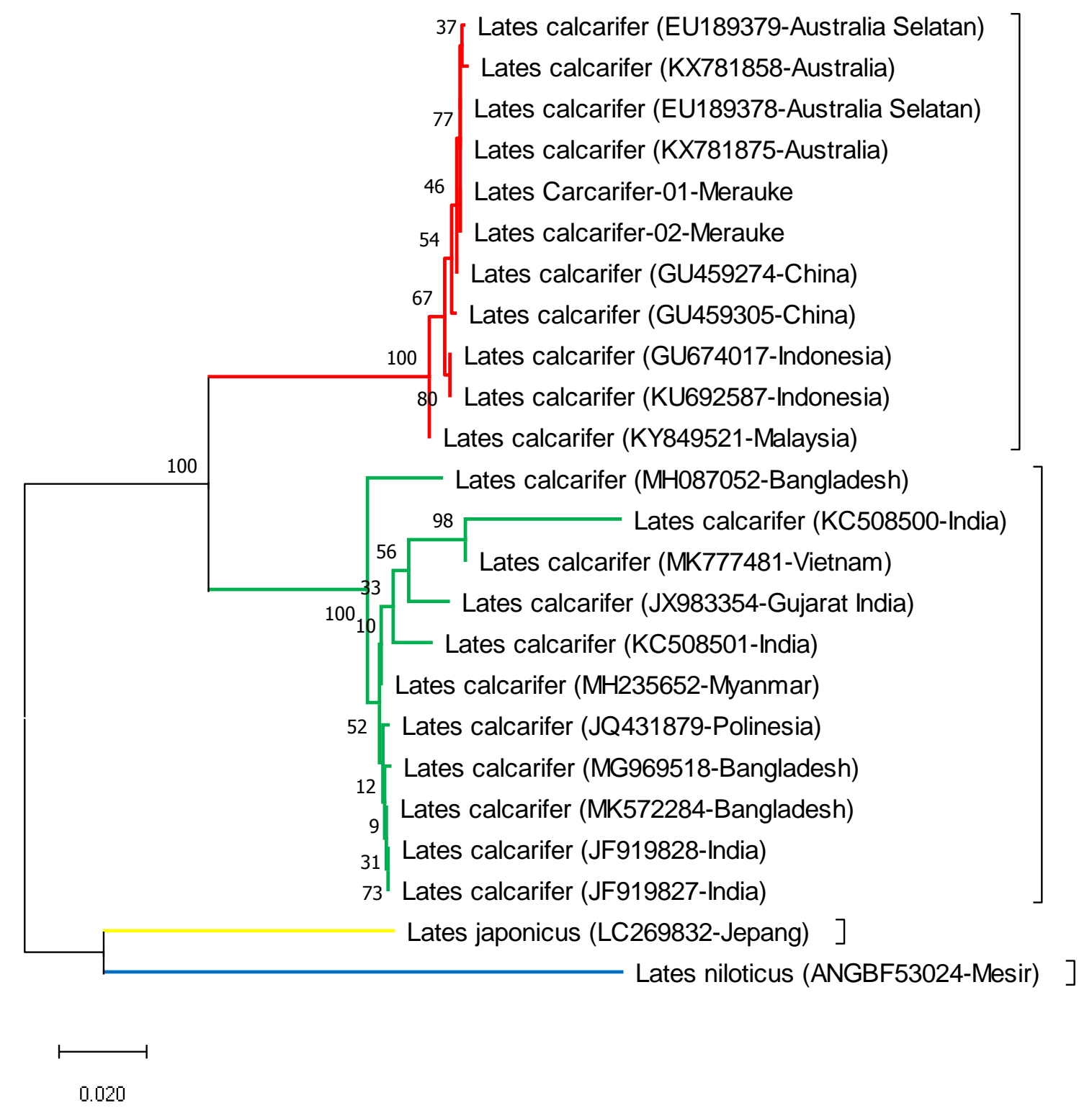

Gambar 2. Rekontruksi pohon filogenetik ikan kakap putih (L. calcarifer) dari Sungai Kumbe Merauke, Papua 
Tabel 2. Komposisi nukleotida ikan kakap putih asal Sungai Kumbe Merauke Papua

\begin{tabular}{ccccccc}
\hline Id & Thymine (\%) & Cytosine (\%) & Adenine (\%) & Guanine (\%) & C + G (\%) & A + T (\%) \\
\hline Merauke 01 & 29.4 & 30 & 21.4 & 19.2 & 49.2 & 50.8 \\
Merauke 02 & 29.4 & 30 & 21.4 & 19.4 & 49.2 & 50.8 \\
Rerata & 29.4 & 30 & 21.4 & 19.4 & 49.2 & 50.8 \\
\hline
\end{tabular}

Tabel 3. Jumlah dan sebaran haplotype ikan kakap putih (Lates calcarifer, Bloch, 1790)

\begin{tabular}{|c|c|c|c|}
\hline No & Haplotipe & Jumlah & Id sampel \\
\hline 1 & Haplotype 1 & 8 & $\begin{array}{l}\text { Merauke 01, Merauke 02, KY849521-Malaysia, EU189379-Australia } \\
\text { Selatan, KX781875-Australia, EU189378-Australia Selatan, } \\
\text { GU459305-China dan GU459274-China }\end{array}$ \\
\hline 2 & Haplotype 2 & 1 & X983354-Gujarat India \\
\hline 3 & Haplotype 3 & 2 & GU674017-Indonesia, KU692587-Indonesia \\
\hline 4 & Haplotype 4 & 8 & $\begin{array}{l}\text { MK572284-Bangladesh, MH235652-Myanmar, JF919828-India, } \\
\text { JF919827-India, KC508501-India, JQ431879-Polinesia, MK777481- } \\
\text { Vietnam dan MG969518-Bangladesh }\end{array}$ \\
\hline 5 & Haplotype 5 & 1 & KX781858-Australia \\
\hline 6 & Haplotype 6 & 1 & KC508500-India \\
\hline 7 & Haplotype 7 & 1 & MH087052-Bangladesh \\
\hline
\end{tabular}

Tabel 4. Jarak genetik antar individu dan spesies Lates sp.

\begin{tabular}{|c|c|c|c|c|c|c|c|c|c|c|c|c|c|}
\hline No & Spesies & 1 & 2 & 3 & 4 & 5 & 6 & 7 & 8 & 9 & 10 & 11 & 12 \\
\hline 1 & $\begin{array}{l}\text { L. calarifer } \\
\text { (Merauke-01) }\end{array}$ & * & $*$ & $*$ & * & * & * & * & * & ${ }^{*}$ & * & ${ }^{*}$ & * \\
\hline 2 & $\begin{array}{l}\text { L. calarifer } \\
\text { (Merauke-02) }\end{array}$ & 0.000 & * & * & * & * & * & * & * & * & * & * & * \\
\hline 3 & $\begin{array}{l}\text { L. calarifer } \\
\text { (GU674017-Indonesia) }\end{array}$ & 0.005 & 0.005 & * & * & * & * & * & $*$ & * & * & * & * \\
\hline 4 & $\begin{array}{l}\text { L. calarifer } \\
\text { (KY849521-Malaysia) }\end{array}$ & 0.008 & 0.008 & 0.003 & * & * & * & * & * & * & * & * & $*$ \\
\hline 5 & $\begin{array}{l}\text { L. calarifer } \\
\text { (KX781875- } \\
\text { Australia) }\end{array}$ & 0.000 & 0.000 & 0.005 & 0.005 & * & * & * & $*$ & * & $*$ & * & * \\
\hline 6 & $\begin{array}{l}\text { L. calarifer } \\
\text { (EU189378- } \\
\text { Australia Selatan) }\end{array}$ & 0.000 & 0.000 & 0.005 & 0.005 & 0.000 & * & * & * & * & * & * & * \\
\hline 7 & $\begin{array}{l}\text { L. calarifer } \\
\text { (JF919827- } \\
\text { India) }\end{array}$ & 0.097 & 0.097 & 0.089 & 0.102 & 0.095 & 0.095 & * & * & * & $*$ & $*$ & $*$ \\
\hline 8 & $\begin{array}{l}\text { L. calarifer } \\
\text { (JF919828-India) }\end{array}$ & 0.097 & 0.097 & 0.089 & 0.102 & 0.095 & 0.095 & 0.000 & * & * & $*$ & $*$ & $*$ \\
\hline 9 & $\begin{array}{l}\text { L. calarifer } \\
\text { (MG969518 Bangladesh) }\end{array}$ & 0.098 & 0.098 & 0.092 & 0.097 & 0.098 & 0.098 & 0.002 & 0.002 & * & * & * & * \\
\hline 10 & $\begin{array}{l}\text { L. calarifer } \\
\text { (MH235652-Myanmar) }\end{array}$ & 0.091 & 0.091 & 0.085 & 0.093 & 0.091 & 0.091 & 0.000 & 0.000 & 0.002 & * & * & * \\
\hline 11 & $\begin{array}{l}\text { L. calarifer } \\
\text { (JQ431879- } \\
\text { Polinesia) }\end{array}$ & 0.096 & 0.096 & 0.089 & 0.098 & 0.095 & 0.095 & 0.002 & 0.002 & 0.003 & 0.000 & * & * \\
\hline 12 & $\begin{array}{l}\text { L. calarifer } \\
\text { (MK777481- } \\
\text { Vietnam) }\end{array}$ & 0.100 & 0.100 & 0.096 & 0.100 & 0.099 & 0.099 & 0.000 & 0.000 & 0.000 & 0.000 & 0.002 & $*$ \\
\hline 13 & $\begin{array}{l}\text { L. calarifer (GU459274- } \\
\text { China) }\end{array}$ & 0.000 & 0.000 & 0.003 & 0.000 & 0.000 & 0.000 & 0.101 & 0.101 & 0.101 & 0.097 & 0.101 & 0.101 \\
\hline
\end{tabular}


filogenetik menggunakan metode NeighbourJoining (NJ) dengan model Kimura 2parameter, nilai bootstrap 1000x. sebagai outgroup digunakan spesies $L$. japonicas dan $L$. niloticus sebagai pembanding. Pohon filogenetik ikan kakap putih (Gambar 2) membentuk 2 clade utama yang mana spesies-spesies yang dianalisis membentuk kelompok sesuai dengan jarak genetik dan kemiripan sekuen DNA.

Pohon filogenetik (Gambar 2) yang terbentuk terdiri atas 2 clade besar dengan nilai boostrap yang tinggi. Semakin tinggi nilai boostrap yang terbentuk semakin baik rekonstruksi pohon filogenetik tersebut. Ikan kakap putih asal Merauke membentuk clade yang sama dengan ikan kakap putih yang berasal dari daerah di Indonesia, Australia, Cina dan Malaysia. Clade yang berbeda terdiri atas ikan kakap putih yang berasal dari Bangladesh, India, Myanmar, Polinesia dan Vietnam. Bergabungnya ikan kakap putih dari beberapa daerah yang berbeda mengindikasikan terjadinya sharring genetik atau gen flow antar wilayah. Sehingga pengelolaan konservasi ikan kakap putih harus dilakukan secara global.

Rekonstruksi filogenetik memperlihatkan terjadinya konektivitas antar lokasi baik Cina, Malaysia, Indonesia dan Australia. Wilayah Bangladesh, India, Polinesia, Myanmar dan Vietnam membentuk konektivitas yang berbeda dengan wilayah lainnya. Jarak geografis antara Merauke dan Australia dapat menyebabkan terjadinya gen flow yang mana pada organisme laut, gen flow terjadi melalui proses migrasi spesies ataupun melalui proses larva dispersal (Jefri, Zamani, Subhan, \& Madduppa, 2015). Rekonstruksi pohon filogenetik, ikan kakap putih asal Sungai Kumbe Merauke memiliki hubungan genetik genetik dengan ikan kakap putih yang berasal dari Australia, Cina dan Malaysia.

\section{KESIMPULAN}

Analisis DNA barcoding diperoleh spesies yang dianalisis adalah ikan kakap putih (Lates calcarifer, Bloch, 1790) dengan panjang sekuen 660 bp. Kesamaan haplotytipe ditemukan antar ikan kakap putih asal Merauke, Australia, Malaysia dan Cina ini mengindikasikan terjadinya gen flow antar lokasi. Pohon filogenetik membentuk 2 clade dengan nilai boostrap 100. Seluruh sekuen terbentuk berdasarkan kemiripan sekuen dan jarak genetik.

\section{DAFTAR PUSTAKA}

Achmad, M.J., Subur, R., \& Akbar, N., 2020. DNA barcode and phylogenetics of green humphead parrotfish (Bolbometopon muricatum) in North Maluku waters. AACL Bioflux, 13(5):2779-2787.

Adams, C.I.M., Knapp, M., Gemmell, N.J., Jeunen, G.J., Bunce, M., Lamare, M.D., \& Taylor, H.R., 2019. Beyond biodiversity: Can environmental DNA (eDNA) cut it as a population genetics tool? Genes, 10(3):p192. doi: 10.3390/genes 10030192

Ahmed, M.S., Datta, S.K., \& Zhilik, A.A., 2020. Molecular diversity of freshwater fishes of Bangladesh assessed by DNA barcoding. Bangladesh Journal of Zoology, 48(1):119. doi: 10.3329/bjz.v48il .47872

Akbar, N., Zamani, N.P., \& Madduppa, H., 2014. Keragaman genetik ikan tuna sirip kuning (Thunnus albacares) dari dua populasi di Laut Maluku, Indonesia. Depik, 3(1):65-73. doi: 10.13170/depik.3.1.1304

Ali, F.S., Ismail, M., \& Aly, W., 2020. DNA barcoding to characterize biodiversity of freshwater fishes of Egypt. Molecular Biology Reports, 47(8):5865-5877. doi: 10.1007/s 1 1033-020-05657-3

Azmir, I.A., Esa, Y., Amin, S.M.N., Md Yasin, I.S., \& Md Yusof, F.Z., 2017. Identification of larval fish in mangrove areas of Peninsular Malaysia using morphology and DNA barcoding methods. Journal of Applied Ichthyology, 33(5):998-1006. doi: 10.1111/ jai. 13425

Dahruddin, H., Hutama, A., Busson, F., Sauri, S., Hanner, R., Keith, P., Hadiaty, R., \& Hubert, N., 2017. Revisiting the ichthyodiversity of Java and Bali through DNA barcodes: taxonomic coverage, identification accuracy, cryptic diversity and identification of exotic species. Molecular Ecology Resources, 17(2):288-299. doi: 10.1111/1755-0998.12528

Dailami, M., Rahmawati, A., Saleky, D., \& Toha, A.H.A., 2021a. DNA barcoding of tilapia fish from Merauke, Papua and Malang, 
East Java-Indonesia. AACL Bioflux, 14(2): 849-858.

Dailami, M., Widyawati, Y., Toha, A. H. A., 2021b. Identifikasi Genetik Ikan Teri dari Teluk Cenderawasih dengan pendekatan DNA Barcoding Genetic Identification of Anchovy from Cenderawasih Bay using DNA Barcoding Approach. Musamus Fisheries and Marine Journal, 3(2):154-166. https://doi.org/10.35724/mfmj.v3i2.3521

Díaz-Ferguson, E., Haney, R., Wares, J., \& Silliman, B., 2010. Population genetics of a trochid gastropod broadens picture of caribbean sea connectivity. PLOS ONE, 5(9):1-8. doi: 10.1371/journal.pone.0012675

Hubert, N., Meyer, C.P., Bruggemann, H.J., Guérin, F., Komeno, R.J.L., Espiau, B., Causse, R., Williams, J.T., \& Planes, S., 2012. Cryptic diversity in indo-pacific coral-reef fishes revealed by DNA-barcoding provides new support to the centre-ofoverlap hypothesis. PLoS One 7(3): p.e28987. doi: 10.1371/journal.pone.0028987

Ibrahim, B., Salamah, E., Hak, N., \& Komalasari, A., 2014. Pengaruh Penyamakan Khrom Kulit Ikan Kakap Putih Dikombinasi Dengan Ekstrak Biji Pinang Terhadap Karakteristik Fisik Kulit. Jurnal Pengolahan Hasil Perikanan Indonesia, 17(2):103-111.

Iwatsuki, Y., Newman, S.J., Tanaka, F., \& Russell, B.C., 2018. Validity of psammoperca datnioides richardson 1848 and redescriptions of $P$. waigiensis Cuvier in Cuvier \& Valenciennes 1828 and Hypopterus macropterus (Günther 1859) in the family Latidae (Perciformes) from the Indo-West Pacific. Zootaxa, 4402(3): 467-486. doi: 10.1 1646/zootaxa.4402.3.3

Jaya, B., Agustriani, F., \& Isnaini, 2015. Laju Pertumbuhan dan Tingkat Kelangsungan Hidup Benih Kakap Putih (Lates calcarifer, Bloch) dengan Pemberian Pakan yang Berbeda Berian. Maspari Journal, 5(1): 5663.

Jefri, E., Zamani, N.P., Subhan, B., \& Madduppa, H., 2015. Molecular phylogeny inferred from mitochondrial DNA of the grouper epinephelus spp. In Indonesia collected from local fish market. Biodiversitas, 16(2):254-263. doi: 10.13057/biodiv/d160221

John, A., Prasannaku, C., Lyla, P.S., Khan, S.A., \& Jalal, K.C.A., 2010. DNA Barcoding of
Lates calcarifer (Bloch, 1970). Research Journal of Biological Sciences, 5(6):414419. doi : 10.3923/rjbsci.2010.414.419

Khedkar, G.D., Jamdade, R., Naik, S., David, L., \& Haymer, D., 2014. DNA barcodes for the Flshes of the Narmada, one of India's longest rivers. PLOS ONE, 9(7):1-10. doi : 10.1371/journal.pone.0101460

Kumar, S., Stecher, G., Li, M., Knyaz, C., \& Tamura, K., 2018. MEGA X: Molecular evolutionary genetics analysis across computing platforms. Molecular Biology and Evolution, 35(6):1547-1549. doi : $10.1093 / \mathrm{molbev} / \mathrm{msy} 096$

Leatemia, S.P.O., Manumpil, A.W., Saleky, D., \& Dailami, M., 2018. DNA Barcode dan Molekuler Filogeni Turbo sp . di Perairan. Prosiding Seminar Nasional MIPA UNIPA Ke-3. 3:103-114.

Madduppa, H., Taurusman, A.A., Subhan, B., Anggraini, N.P., Fadillah, R., \& Tarman, K., 2017. Short communication: Dna barcoding reveals vulnerable and not evaluated species of sea cucumbers (Holothuroidea and Stichopodidae) from Kepulauan Seribu reefs, Indonesia. Biodiversitas, 18(3):893-898. doi : 10.130 57/biodiv/d 180305

Martinez, A.S., Willoughby, J.R., \& Christie, M.R., 2018. Genetic diversity in fishes is influenced by habitat type and life-history variation. Ecology and Evolution, 8(23): 12022-12031. doi : 10.1002/ece3.4661

Mitchell, A., Rothbart, A., Frankham, G., Johnson, R.N., \& Neaves, L.E., 2019. Could do better! A high school market survey of fish labelling in Sydney, Australia, using DNA barcodes. PeerJ, 7(2019):e7138. doi: 10.7717/peerj.7138

Nugraha, B., Novianto, D., \& Barata, A., 2011. Keragaman Genetik Ikan Tuna Mata Besar (Thunnus obesus) Di Samudera Hindia. Jurnal Penelitian Perikanan Indonesia, 17(4):277284.

Nuryanto, A., \& Solihin, D.D., 2006. Variasi Sekuens Gen Mitokondrial Sitokrom C Oksidase I dari Siput Lola (Trochus niloticus). Biosfera, 23(1):31-37. doi: 10.20884/1.mib.2006.23.1.143

Pramono, T.B., Arfiati, D.A., Widodo, M.S., Yanuhar, U.Y., 2017. Identifikasi lkan Genus Mystus Dengan Pendekatan Genetik. 
Jurnal Sumberdaya Akuatik Indopasifik; $1(2)$ :123-132, doi: 10.30862/js ai-fpiknipa.2017.Vol.1.No.2.34

Rachmat, H.H., Subiakto, A., \& Kamiya, K., 2016. Short Communication: Genetic diversity and conservation strategy considerations for highly valuable medicinal tree of Taxus sumatrana in Indonesia. Biodiversitas, 17(2):487-491. doi: 10.13057/biodiv/d170213

Rahman, M.M., Norén, M., Mollah, A.R., \& Kullander, S.O., 2019. Building a DNA barcode library for the freshwater fishes of Bangladesh. Scientific Reports, 9(1):9382. doi: 10.1038/s41598-019-45379-6

Rajasekar, M., Thangaraj, M., Barathkumar, T. R., Subburaj, J., \& Muthazhagan, K. 2012. Genetic Diversity Analysis of Lates calcarifer (Bloch 1790) in Captive and Wild Populations Using RAPD Markers. Notulae Scientia Biologicae, 4(3):33-37. doi: 10.15835/nsb43,7896

Ran, K., Li, Q., Qi, L., Li, W., \& Kong, L. 2020. Molecular identification of Cerithiidae (Mollusca: Gastropod) in Hainan island, China. Mitochondrial DNA Part A: DNA Mapping, Sequencing, and Analysis, 31 (2):57-63. doi: 10.1080/24701394.2020. 1726898

Rozas, J., Ferrer-Mata, A., Sanchez-DelBarrio, J. C., Guirao-Rico, S., Librado, P., RamosOnsins, S.E., \& Sanchez-Gracia, A., 2017. DnaSP 6: DNA sequence polymorphism analysis of large data sets. Molecular Biology and Evolution, 34(12):3299-3302. doi: 10.1093/molbev/msx248

Saleky, D., Leatemia, S.P., Pattiasina, T.F., Isma, I., Pangaribuan, R.D., Welliken, M.A., Melmambessy, E.H.P., \& Dailami, M., 2020. Analisis Pola Pertumbuhan dan Pendekatan DNA Barcoding untuk Identifikasi Turbo stenogyrus P. Fischer, 1873 (Mollusca: Gastropoda). Biotropika: Journal of Tropical Biology 8(2):79-86. doi:10.21776/ub.biotropika.2020.008.02.03

Saleky, D., Setyobudiandi, I., Toha, A.H.A., Takdir, M., \& Madduppa, H., 2016. Lengthweight relationship and population genetic of two marine gastropods species (Turbinidae: Turbo sparverius and Turbo bruneus) in the Bird Seascape Papua, Indonesia. Biodiversitas, Journal of
Biological Diversity, 17(1):208-217. doi: 10.13057/biodiv/d 170130

Saleky, D., Supriyatin, F. E., \& Dailami, M., 2020. Pola Pertumbuhan dan Identifikasi Genetik Turbo setosus Gmelin, 1791 [Turbinidae, Gastropoda]. Jurnal Kelautan Tropis, 23(3):305-315. doi: 10.14710/jkt.v23 i3.7514

Segura-García, I., Tun, T.Y., \& Box, S.J. 2018. Genetic characterization of the artisanal mud crab fishery in myanmar. PLOS ONE, 13(9):1-13. doi: 10.1371/journal.pone.0204905

Sohpal, K.V., 2013. Computational Analysis of Distance and Character based Phylogenetic Tree for Capsid Proteins of Human Herpes Virus. Journal of Data Mining in Genomics \& Proteomics, 4(2): 2153-0602. doi : $10.4172 / 2153-0602.1000128$

Thu, P.T., Huang, W.C., Chou, T.K., Van Quan, N., Van Chien, P., Li, F., Shao, K.T. \& Liao, T.Y. 2019. DNA barcoding of coastal rayfinned fishes in Vietnam. PLOS ONE, 14(9): 1-13. doi: 10.1371/journal.pone.0222631

Wang, Z.D., Guo, Y.S., Liu, X.M., Fan, Y.B., \& Liu, C.W., 2012. DNA barcoding South China Sea fishes. Mitochondrial DNA, 23(5):405410. doi: 10.3109/19401736.2012.710204

Ward, R.D., Holmes, B.H., \& Yearsley, G.K., 2008. DNA barcoding reveals a likely second species of Asian sea bass (barramundi) (Lates calcarifer). Journal of Fish Biology, 72(2):458-463. doi: 10.1111/j.1095-8649. 2007.01703.x

Weigand, A.M., Jochum, A., Slapnik, R., Schnitzler, J., Zarza, E., \& Klussmann-Kolb, A., 2013. Evolution of microgastropods (Ellobioidea, Carychiidae): integrating taxonomic, phylogenetic and evolutionary hypotheses. BMC Evolutionary Biology, 13(1):13-18. doi: 10.1 186/1471-2148-13-18

Widodo, M.H., Edy H.P., \& Melmambessy, S.M., 2016. Potensi Kakap Putih (Lates calcalifer Bloch, 1790) Di Sungai Kumbe Distrik Malind Kabupaten Merauke. Agricola, 6(1):2565-2568.

Yue, G.H., Zhu, Z.Y., Lo, L.C., Wang, C.M., Lin, G., Feng, F., Pang, H.Y., Li, J., Gong, P., Liu, H.M., Tan, J., Chou, R., Lim, H. \& Orban, L., 2009. Genetic variation and population structure of Asian seabass (Lates calcarifer) in the Asia-Pacific region. Aquaculture 293: 22-28. doi : 10.1016/ 
j.aquaculture.2009.03.053

Yusron, E., 2005. Pemanfaatan keragaman genetik dalam pengelolaan sumberdaya hayati laut. Oseana, 30(2):29-34.

Zhang, J., 2010. Exploiting formalin-preserved fish specimens for resources of DNA barcoding. Molecular Ecology Resources, 10(6):935-941. doi : 10.1111/j.155-0998.20 10.02838.x 